\title{
The Equivalent of Dixon's Take Subtype of Motion- C Verbs in English and Buginese: Dixon Semantic Approach
}

\author{
Nur Hikmah ${ }^{1}$, Hamzah A. Machmoed ${ }^{2}$, Harlinah Sahib ${ }^{3}$ \\ ${ }^{1,2,3}$ English Language Studies-Postgraduate Program, Faculty of Cultural Sciences - Hasanuddin University, Makassar, South \\ Sulawesi, Indonesia
}

\begin{abstract}
This research aims to (1) identify the motion-c verbs in English and Buginese based on Dixon's division of Take subtype, and to (2) investigate and analyze both similarities and differences of motion-c verbs of Take subtype in English and Buginese in term of semantic. The data of this research consist of English and Buginese Language. The first data (English) collected from COCA (Corpus of Contemporary American English), and the second data (Buginese) obtained from field research by observing and interviewing. Both data were studied with descriptive and qualitative analysis. The result of this research indicated that (1) there are eight motion-c verbs of Take subtype in English: take, bring, fetch, send, move, raise, steal, and lift. In Buginese data, there are twenty-nine verbs refer to motion-c verbs: mala, majjeppu, mangampai (take); tiwi, mattappi, majjujuug, mangessang, mallempa, makkokkong, mabbiccang, mangule, massoppo, marrenreng, matteteng, matteke, mangepa, maddenge' (bring); aleng (fetch); makkiring, mappelaluang (send); mesa, lette', lesse', soro' (move); mappenre' (raise); mennau, majjikkau, mallariang (steal); and mangaka' (lift). The key differences of motion-c verbs in English and Buginese based on Take subtype can be seen from two aspects: locus role and a stance of moving or the way something moved related to the social culture.
\end{abstract}

Keywords: Motion-c verbs, semantic types of verbs, social culture, locus.

\section{INTRODUCTION}

$\mathrm{T}$ The study of language with a set of rules is known as linguistics. Linguistics has also been well-defined by some linguists. According to Wardhaugh[1], linguistics is the scientific study of language. In addition, Halliday[2] argues that linguistics as the study of how people exchange meaning by 'languaging'. In brief, linguistics is the study of language associated with how the words are put and arranged together in certain order and how it functions in creating meaning. Furthermore, linguistics is constituted of some disciplines, such as phonology, syntax, morphology, as well as semantics. Linguistics is also a part of language and culture that cannot be separated because they are the social and people behavior's expressions[3]. As euphemism form and function of euphemism in Bachriani et al[4] said that Buginese more complex than euphemism form and function in English. Meanwhile, Zulkhaeriyah et al[5] stated that the Buginese people employ indirect apology such as acknowledgment of responsibility, explanation, an offer of repair, interjection, address term in their apology, it describe apology as "a speech act set te $^{\text {which }}$ is comprised of some potential semantic formulas .

Dealing both grammar and words, there is semantics. It is considered as the study of meaning. As Palmer[6] states that, semantics is the technical term used to refer to the study of meaning. Besides, according to Griffiths[7], the branch of the linguistics study related to the meaning is semantics. From the definitions of semantics given above can be inferred that semantics is totally about meaning or the scientific study of meaning.

In relation, Dixon is also delivering his ideas about semantics through his work. Dixon[8] argues that semantics is the organization of meaning. Because language is utilized, meaning is both the beginning and the final point, meaning is related with the way words are joined to make phrases, clauses, and sentences. Thus, he explores the basic principle of language as a complex phenomenon, whose pieces meet or across together in complex way by demonstrating how those interrelate, the meaning of words and the grammatical constructions as a large part of the basis.

Dixon[8] provides some semantics types of verbs, such as in Primary-A verb type which concerns Giving verb, Rest verb, Corporeal, Weather, Affect, as well as Motion verb. This Motion verb can be recognized by seven subtypes. Those are Motion-a up to the Motion-g. Verb take, bring, fetch, send, move, raise, lift, and steal, those make up one type called 'Take' subtype of Motion-c. For instance, in English, the word bring which has some equivalents in Buginese such as tiwi, mangessang, majjujung, and mattappi. When these are compared in English based on the grammar componential analysis, it will show as follows:

English

Bring $\quad=[+$ by hand $],[-$ by shoulder $],[-$ by waist $]$

VS.

Buginese

mangessang $=[-$ by hand $],[+$ by shoulder $],[-$ by waist $]$ 
English

Bring $\quad=[+$ by hand $],[-$ by shoulder $],[-$ by waist $]$

vs.

Buginese

tiwi $\quad=[+/$ - by hand $],[+/-$ by shoulder $],[+/-$ by waist $]$

In other words, the word bring in English has three basic factors: bring by hand, bring not by shoulder, and bring not by waist. Meanwhile, the word mangessang (bring) in Buginese also can have three basic factors or semantic properties: bring not by hand, bring by or on shoulder, and bring by waist. While the word tiwi (bring) has semantic properties: bring or bring not by hand, shoulder, and waist.

Motion-c verbs in one language always have differences with other languages. For example, the verb brings in English has some equivalents in Buginese. They are mangessang means you bring something by putting it on your shoulder. Mattappi which refers you bring something by putting or binding it besides your waist. Tiwi deals with you are causing something to be in motion by bringing it with your hand. Majjujung indicates causing something to be in motion by bringing it on your head, etc.

Considering the explanation above, the researcher is interested in conducting research about Motion-c verbs in English and Buginese. From the two languages (English and Buginese), the researcher would like to see whether 'Take' subtype of Motion-c verbs proposed by Dixon in English can be generalized into whole Buginese Motion-c verbs referring 'Take' subtype. Besides, the researcher chooses Buginese language to be compared with English or to be studied because as well as its spreading in Indonesia as a regional language makes it very important to be learned by other people in different region to understand the language aspects of Buginese, especially in written text and how they are different with English.

Some previous researchers conducted about Dixon semantic approach they are: 1) Melansari[9] conducted a study about motion verb in English and Wolio language. She used qualitative in identifying the motion verb in both languages and she also investigate how the motion verb in both languages differs in their meaning then it could be affecting their grammatical properties. There have been 82 motions in English and 85 motion verbs in local language (Wolio) that had been identified. The motion verbs in both languages are not always similar in their meanings. In addition, there is special phenomenon occur in local language that is some of the 'Arrive' verbs and bawa (to take) in Wolio need ling $k a$ (to go) to represent movement to a certain location, and to establish that the meaning of the preposition "yi" corresponds to the word "to". 2) Suriati[10] organized a research about Give verb of English and Kasi verb of Kupang Malay language. It is a review on Dixon's Giving semantic type theoretical framework. She analyzed the construction and the extended meaning of English 'give' verb and kasi verb in Kupang language. The researcher used qualitative method and found out that the basic constructions of both languages are the same, but different in grammatical properties that result in different meaning. The 'recipient' and 'donor' could be omitted when an adverb such out, away, and back is added to 'give' verb. Indicating general giving activity in Kupang Malay, a verb and noun can be added in Kasi verb. In the construction, all the roles can be either omitted or stated. The literal meaning of both verbs can extent to grammatical meaning metaphorically, but 'give' verb exhibit more variations. The different of historical development of language and sociolinguistic characteristic of 'give' verb and kasi verb become the reason of the phenomenon happened.

In systemic functional linguistic theory, transitivity is one of its branches to analyze clauses[11]. This research also investigates and compares the verbs subtype by Dixon[8] with the use of verbs variation in the local language that is Buginese. The difference of this study from the studies that have been conducted is the presented of the variation of verbs 'Take' which has three positions from Dixon's theory and differences meaning between English and Buginese.

\section{LITERATURE REVIEW}

\section{a) Semantic type}

This following discussion of semantic type based on Dixon's[8] explanations. A semantic type is a collection of words that share a common meaning element. At the semantic level, these words are naturally classified into large classes in the same way. For instance, some verbs such as big, great, short, thin, round, narrow, and deep are grouped as the Dimension type. Verb such as begin, start, commence and some others are gathered as the Beginning type. He divides words which have common meaning components into large groups that are called semantic type. He divides semantic types only for major word classes which have a huge and potentially limitless membership, such as noun, adjective, and verb.

\section{b) Dixon's Take subtype of Motion-c verbs}

According to Dixon[8], Take subtype of Motion-c verbs refers to causing something to be in motion with respect to a locus. This subtype deals with three sets. Those are (i) take, bring, fetch; (ii) send; (iii) move, raise, and steal. These are entirely transitive verbs with a Causer which generally human in A function. Set (i) includes double realization of moving role, both A and O NPs normally designate to something in motion. For instance, Mary (Causer; moving) bought her cat (moving) to the market. Thus, the role common to Motion-c verbs is (thing) moving and there is a Causer which typically human.

Most of Take verbs are like Arrive in requiring specification of locus. However, take and bring, the transitive correspondents of go and come, it has as a part of their 
meaning the specifications 'to there' and 'to here' respectively. Thereby, there might be omitted after the word take and here after bring. Fetch is a combination of go (to where something is) and bring (it back to the opening point). In using the verb fetch, 'here' is implied and can be omitted.

In set (ii) includes send. Send contains a Causer arranging for a moving thing to go and not normally accompanying it. Moreover, a locus in this set should be specified. For example, I sent the cow to market (except it could be inferred from the preceding discourse). Other examples, have you got in touch with Rina yet? Well, I sent a letter. In other hand, take, bring, fetch, and send can be used with the additional implication of 'giving'. Such when it compared take the fish to market (a destination) with take the fish for/to John (for is possible to infer a recipient, and to might mark recipient).

In set (iii) move may be transitive or intransitive. This verb refers to motion with respect to numerous locuses rather than a general mode of motion like Run. For instance, Siti moved from Makassar to Gowa. Additionally, move can be used with a broad adverb or with no explicit location definition. For example, He's always moving (about), or She's always moving the chairs (around). The meaning of the word, on the other hand, clearly implies "from this place to that place or to another place." The verbs raise and lift have a similar effect.

Steal in set (iii) is a more specific verb. It is a transitive move in which the moving role (in $\mathrm{O}$ function) refers to anything that does not belong to the Causers and should not have been taken or moved by them. The locus NP is optional, it is often included, or it is not essential, and the attention is on the nature of the referent of moving role. For example, he stole ten dollars (from Jane' purse).

\section{OBJECTIVE OF THE STUDY}

There are two objectives of this study. The first is to identify Motion-c verbs in English and Buginese based on the "Take" subtype divided by Dixon. The second one is to investigate and analyze the differences and similarities in term of semantic and grammatical construction of "Take" subtype of Motion-c verbs in English and Buginese

\section{METHODOLOGY}

In doing this research, the researcher used descriptive qualitative method. This method explains about the data in relation to words and sentences. It avoids using number or quantification. This method is intended to collect the data and analyze it to compare the meaning and grammatical structure of Motion-c verbs in English and Buginese. Both languages' motion-c verbs will be given descriptively in the form of a comparison. This research is also conducted in the field and in the library.

In collecting the data, the observation begins by collecting the English data from Corpus of Contemporary American Language (COCA). The variants of data will be taken from the formal and informal content of conversation, text, and other sources from corpus which have any correlation to the topic of this research. In gaining the information the researcher will organize interviewing and recording. In collecting the Buginese or the local language data, the researcher would like to interview the chosen informant, those basically living in the Buginese area which uses Buginese in their daily conversation. Moreover, the recording will be taken by using smart phone's during the interviewing to get easier in analyzing the data by listening it carefully. In addition, note taking will be done to keep and mark the important point of data which obtained from interviewing and recording. The data will be collected as much as possible from all kinds of book, journal, thesis, and magazine or some text that related to the topic until the problem of the research can be solved.

After the process of collecting data, the researcher analyzed the data. There were several steps that were applied in order to analyze Dixon's take subtype of motion-c verbs in English and Buginese. The first step was to do intensive reading on the data. The second step was applying the theory in order to identify all Dixon's take subtype of motion-c verbs in English and Buginese that can be found in data. The last step was to draw conclusion from the data analysis.

\section{FINDING AND DISCUSSION}

\subsection{Findings}

This chapter outlines the Take Subtype in English and Buginese completely including the differences between the two languages as the results. It is divided into two parts; finding displays the data and discussion. The case is in 'Take and Mala, Majjeppu, Mangampai':

\subsubsection{English Data (Take)}

Table 1. Data 1

\begin{tabular}{|c|c|c|}
\hline I & Take the book & From her \\
\hline Causer & Moving & Locus \\
\hline
\end{tabular}

Table 2. Data 2

\begin{tabular}{|c|c|c|}
\hline She & took the flash & from Owen \\
\hline Causer & Moving & Locus \\
\hline
\end{tabular}

Table 3. Data 3

\begin{tabular}{|c|c|c|}
\hline She & took the drug & - \\
\hline Causer & Moving & Locus \\
\hline
\end{tabular}

Table 4. Data 4

\begin{tabular}{|c|c|c|}
\hline She & $\begin{array}{c}\text { took tens of millions of } \\
\text { dollars }\end{array}$ & $\begin{array}{c}\text { between the library and } \\
\text { foundation }\end{array}$ \\
\hline Causer & Moving & Locus \\
\hline
\end{tabular}




\subsubsection{Buginese Data (Mala, Majjeppu, and Mangampai)}

Table 5. Data 5

\begin{tabular}{|c|c|c|c|}
\hline Mala & $-\mathrm{i}$ & nanre & - \\
\hline Moving & Causer & & Locus \\
\hline
\end{tabular}

Buginese:

Mala-i nanre

Take-he rice

'He takes the rice'

Table 6. Data 6

\begin{tabular}{|c|c|c|}
\hline Mala & -ka otti & ri dare'na \\
\hline Moving & \multicolumn{2}{|c|}{ Causer } \\
\hline
\end{tabular}

Buginese:

Mala-ka otti ri dare'-na

Take-I banana in farm-his

'I took banana in his farm'

Table 7. Data 7

\begin{tabular}{|c|c|c|c|}
\hline Majjeppu & $-\mathrm{i}$ & beppa & $\begin{array}{c}\text { ri yase'na } \\
\text { mejang'e }\end{array}$ \\
\hline Moving & Causer & & Locus \\
\hline
\end{tabular}

Buginese:

Majjeppu-i beppa riyase'na mejang-'e

Take-she cookie on tabel-the

'She takes the cookie on the table'

Table 8. Data 8

\begin{tabular}{|c|c|c|c|}
\hline U- & jeppu & karoppo'na & - \\
\hline Causer & Moving & & Locus \\
\hline
\end{tabular}

Buginese:

U-јерри karoppo'-na

I-took snack-his

'I took his snack'

Table 9. Data 9

\begin{tabular}{|c|c|c|c|}
\hline Mangampai & $-\mathrm{i}$ & $\begin{array}{c}\text { sikatoang golla } \\
\text { cella }\end{array}$ & - \\
\hline Moving & Causer & & Locus \\
\hline
\end{tabular}

Buginese:

Mangampai-i si-katoang golla cela

Take-he a-bucket sugar brown

'He takes a bucket of brown sugar'

Table 10. Data 10

\begin{tabular}{|c|c|c|c|}
\hline Beddu & Mangampai & bere' wenni' & - \\
\hline Causer & Moving & & Locus \\
\hline
\end{tabular}

Buginese:

$\begin{array}{llll}\text { Beddu mangampai } & \text { bere' } & \text { wenni' } \\ \text { Beddu take } & \text { rice } & \text { yesterday }\end{array}$

'Beddu took the rice yesterday'

Table 11. Data 11

\begin{tabular}{|c|c|c|c|}
\hline Mangampai & $-\mathrm{ka}$ & kaliki & - \\
\hline Moving & Causer & & Locus \\
\hline
\end{tabular}

Buginese:

$\begin{array}{ll}\text { Mangampai-ka } & \text { kaliki } \\ \text { Take-I } & \text { papaya }\end{array}$

'I took the papaya'

The data show there are three equivalents in Buginese of verb the 'take'. In English data (1), (2), and (4) the verb 'take' as moving role is followed by the specification of locus, such from her, from Owen, and between the building and foundation. In English only have one verb which means take or causing something move. While in Buginese data, some words that have similar meaning with verb 'take' are differentiated by the way those things are taken. Such as which one means to take something above by hand (mangampai), which one tends to take something small by finger (majjeppu) and which one means both of them (mala). Thus, it would be more specific such shown on the componential analysis.

Based on the Buginese data, the role of locus of verb mala and majjepu are optional. It can be using locus or without locus, such on data (5), (8), and (9) they are nonlocus, while in data (6) and (7) those verbs are using locus, they are dare'na (his farm) and ri yase'na mejang'e (on the table). Based on data above, mangampai did not provide a locus on the data because its verb already describes a clear locus in its meaning of verb that is above. Therefore, Buginese people are never or seldom to put a specific locus when they use this verb (mangampai) because this is such a special given word from Buginese culture, where it can cover a clear meaning within one word. While in English, people have to describe a comprehensive meaning in a clear clause or sentence in order to obtain such an intelligible meaning as mangampai

. It indicates 'take' verb in English is more general than Buginese or in other words, Buginese is more likely specific.

In data (5) and (6), the verb mala used nanre (rice) and otti (banana) as its moving object since it means to take something either by hand or finger. As people know, taking something by finger means taking a quite small things or light as the meaning of majjeppu. It is related to the next data (7) and (8) provided a different moving object, those are beppa (cookies) and karoppo (snack) it tends to use majjeppu because those things are small and it easier to be taken by fingers. It different from others data that occurred on data (9), (10), and 
(11) which the moving object belong to the heavy things because mangampai indicates taking somebody or something heavy above by hand.

\subsection{Discussions}

\subsubsection{Motion-c Verbs in English and Buginese Based on Take Subtype Divided by Dixon}

There are eight verbs concerning motion verbs of Take subtype in English. They are take, bring, fetch, send, move, raise, lift, and steal. The researcher found there are twenty-nine verbs refer to motion verbs in Buginese, they are mala, majjeppu, mangampai, tiwi, mattappi, majjujung, mangessang, mallempa, makkokong, mabbiccang, mangule', massoppo, marrenreng, matteteng, matteke, mangepa, maddenge', aleng, makkiring, mapplaluang, mesa, lette', soro', lesse', mappenre', mangakka', mennau, majjikau, and mallariang. Some verbs have some similar meaning with Take verb in English, such mala, majjeppu, and mangampai. While tiwi, mattappi, majjujung, mangessang, mallempa, makkokkong, mabbiccang, mangulle, massoppo, marrenreng, matteteng, matteke, mangepa, and maddenge' have an equivalent meaning with the verb Bring in English. Besides, Fetch has similar meaning with aleng and the word send have two equivalents in Buginese, those are makkiringan and mappelaluang. Move has similar meaning with mesa, lette, soro', and lesse'. Mappenre' has equivalent with the verb raise in English. The verb lift only has mangakka' as its equivalent in Buginese, and the word steal is similar to the verb mennau, majjikkau, and mallariang in Buginese.

The Buginese motion verbs which have similar meaning with Take subtype verbs in English specify the human body parts as the locus in the meaning of the verb itself, such as mattappi, massoppo, maddenge', majjujung, mangepa, mabbiccangan and matteteng. In marenreng the verb does not specify the human body part but the way something bring. In addition, the word mallempa specifies the tool that is used to bring something. The verb tiwi neither specify the human body part as the locus nor the way something brought because this verb indicates something can be brought in bag, pocket or purse.

Since the specification of human body part, tool and the way something taken is reflected from the verb itself, it can be seen that the preposition shows the non-moving locus, such as dare' (farm), galung (rice field), pasa' (market), kantoro' (office), bujung (well), and bulu' (mountain).

\subsubsection{The Similarities and Differences of Motion Verbs of Take Subtype in English and Buginese}

\section{a. Locus}

As data found in this research, in English only have a verb that means bring by hand/on hand, bring in bag, bring on shoulder and bring on back. Therefore, this verb does not imply the meaning of verb itself. In Buginese data, some verbs that have similar meaning with verb bring are differentiated which one means bring on the shoulder, which one refers to bring on hand or which one tends to bring in bag. For instance, the verb which means bring on head is majjujung, the one which belongs to bring on shoulder is massoppo. The verb that refers to bring over the shoulder is mangessang. While the verb that means bring in arm is makkokkong. The verb which means bring on hip and bring on back is mangepa' and maddenge'. The one which referes to bring on hand is matteteng and the one which means bring with hand is mabbiccang, while the verb that means both of them (bring in hand, bag or pocket and bring with hand) is tiwi. Thus, in English may have only one verb which imply the meaning itself or does not specify the locus from its verb while in Buginese, some verbs could imply the specification of locus on their meaning or even the way things are taken in term of Take subtype.

\section{b. A Stance of Moving or The Way Something Moved Related to English and Buginese Culture.}

Language was a product of culture because it always represents the cultural activities. In Buginese society of Bone district, particularly in Ajangale', language could have complex meaning based on the context and the situation of the society. Such a stance of moving or the way something moved especially in Take subtype verbs which in the cultural system of Buginese could have several different meanings. Take verbs in Buginese also could mean polite and impolite since people still use term 'Puang' which means she/he is nobility while others are ordinary people. Therefore, polite and impolite also happen through this situation. Such the verb mala in Buginese which is usually used to nobility people is polite to apply instead of using majjeppu to talk to them (nobility people), even those verbs have the same meaning. For instance, Puang, alaki beppa! (Puang, take the cookies please!) better than jeppu'ki beppa Puang!. Thereby, the verb majjeppu sometimes used to ordinary people or it is seldom used to talk to the nobility people.

Other verb which has similar meaning with take is mangampai. It is one of the verbs which have a special meaning where the locus can be implied from the verb itself. The locus here is the particular locus which different from others, that is above the people that will take the things. As the meaning of mangampai which refers to take something above or in a higher place/position then us (causer), in other words this verb implies the clear and specific locus. Moreover, this verb only exists in Buginese because the old Buginese societies use their traditional house which called 'Rumah Panggung'. This house has some tall trusses or poles. Thus, when Buginese people want to ask for somebody to take something from that kind of house, they usually use verb 'mangampai'. Thereby, this verb not only describes the specific locus but also the way something taken or moving style (from above to the ground). 


\section{CONCLUSION}

There are eight motion-c verbs of Take subtype in English. They are take, bring, fetch, send, move, raise, steal, and lift. While in Buginese, there are twenty-nine motion verbs of Take subtype found in this research. Those are mala, majjeppu, mangampai, tiwi, mattappi, majjujung, mangessang, mallempa, makkokkong, mabbiccang, mangule, massoppo, marrenreng, matteteng, matteke, mangepa, maddenge, aleng, makkiring, mappelaluang, mesa, lette', lesse', soro', mangakka, mappenre', mennau, majjikkau, and mallariang. There are several verbs which implied the specification of human's body part as locus in their meaning such as tiwi, massopo, maddenge', mangepa, majjujung, matteteng, marrenreng, mabbiccang and mangule. In addition, there are also verbs that not only implied the part of human's body but include the tool which used into its meaning such as mallempa, and matteke.

The meaning difference between English motion verbs of Take subtype and Buginese motion verbs cause the different of semantic. The main differences of motion-c verbs of Take subtype in English and Buginese can be seen from a role of locus and a stance of moving or the way something moved related to the social culture. Most of the Buginese take subtype verbs reflect to the human's body part in their meaning as a locus. Therefore, locus can be optional because it can be implied from the verb itself. While in English, take verbs need locus. It contrasts with Dixon's statement itself. Thus, Dixon theory in this Take subtype cannot be generalized into whole Buginese motion-c verbs referring Take subtype. From a stance of moving or the way something moved aspect, cultural background plays significant role defining the variants of the motion-c verbs. Such as in the social background which could mean polite or impolite and the traditional house.

\section{REFERENCES}

[1] R. Wardhaugh, Introduction to Linguistics. New York: McGrawHill, Inc., 1972.

[2] M. A. K. Halliday, Introduction to functional grammar. London: Arnold, 1985.

[3] M. R. A. Latief, N. J. Saleh, and A. Pammu, "The effectiveness of machine translation to improve the system of translating language on cultural context," IOP Conf. Ser. Earth Environ. Sci., vol. 575, no. 1,2020 , doi: $10.1088 / 1755-1315 / 575 / 1 / 012178$.

[4] B. Bachriani, A. H. Yassi, and F. Rahman, "A Comparative Study of Euphemism in English and Buginese: Pragmatic Stylistics Contexts," ELS J. Interdiscip. Stud. Humanit., 2018, doi: 10.34050/els-jish.v1i4.5760.

[5] Zulkhaeriyah, N. J. Saleh, A. H. Yassi, and F. Rahman, "Strategy of Apology in Buginese: A Sociolinguistic Study," ELS J. Interdiscip. Stud. Humanit., vol. 4, no. 2, pp. 188-196, 2021, doi: https://doi.org/10.34050/elsjish.v4i2.14015.

[6] F. R. Palmer, Semantics A New Outline. London, New York, Melbourne: Cambridge University Press, 1976.

[7] Patrick Griffith, An Introduction to English Semantics and Pragmatics. Edinburgh: University Press, 2006.

[8] R. M. W. Dixon, A Semantic Approach to English Grammar, Second. New York: Oxford University Press, 2005.

[9] N. Melansari, "Motion Verbs in English and Wolio Language: A Semantic Point Of View," Hasanuddin University, 2005.

[10] S. M. Mandala, "Kata Kerja Memberi pada Bahasa Inggris dan Bahasa Melayu Kupang: Sebuah Review Kerangka Teori Tipe Semantik," 2016.

[11] D. P. S. Husba, A. H. Yassi, and N. J. Saleh, "Transitivity Analysis of Sexual-Related Language in Eka Kurniawan's Cantik Itu Luka and its English Version," J. Ilmu Budaya, vol. 9, no. 2, pp. 1-5, 2021. 